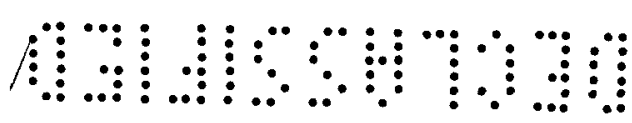

GonicinenITIA

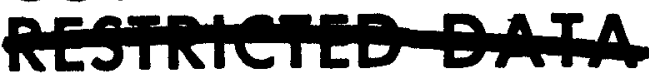

Atomic Energy Act - 1954

WANL-TME-494

August 20, 1963

\title{
FACTORS INVOLVED IN THE ELIMINATION OF THE FUEL ELEMENT ALIGNMENT SLEEVES
}

\section{NOTICE}

This report was prepared as an account of work sponsored by the United States Government. Neither the United States nor the United States Energy Research and Development Administration, nor any of their employees, nor any of their contractors, subcontractors, or their employees, makes any warranty, express or implied, or assumes any legal liability or responsibility for the accuracy, completeness or usefulness of any information, apparatus, product or process disclosed, or represents that its use would not infringe privately owned rights.

\section{(TITLE UNCLASSIFIED)}

\section{SUBMITTED BY:}

\section{Westinghouse Electric Corporation \\ Astronuclear Laboratory \\ Pittsburgh 36, Pennsylvania}

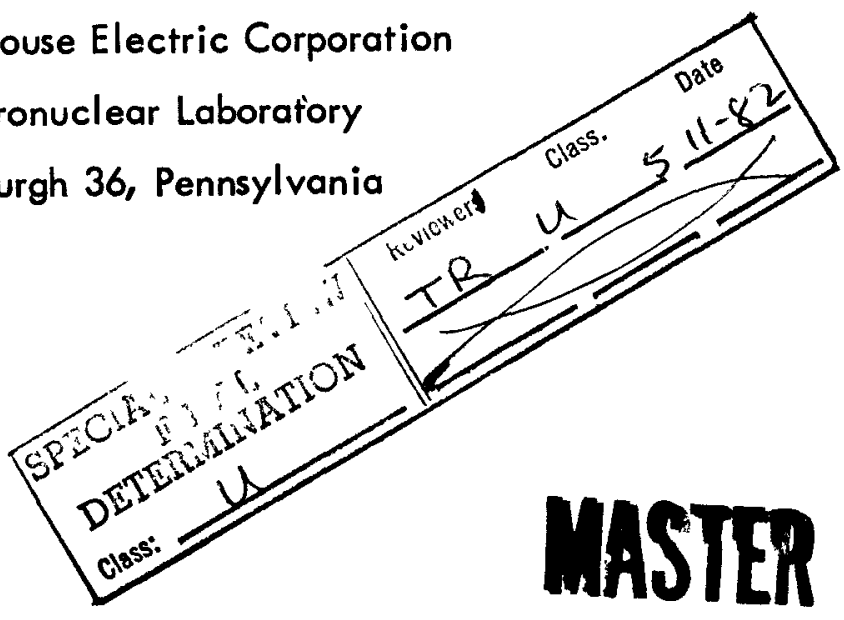

APPROVED BY:

W. H. Esselman, Manager

Engineering and Development

NERVA Project

PREPARED BY:

W.H. Amale/NGg.R.

Depux Manager for Analysis

NERVA Engineering and Development

W.H. Esoluman
INFORMATION CATEGORY

Confidential-Restricted Data

$\frac{\text { W. H. Eselman }}{\text { Authorized Classifier Date }}$
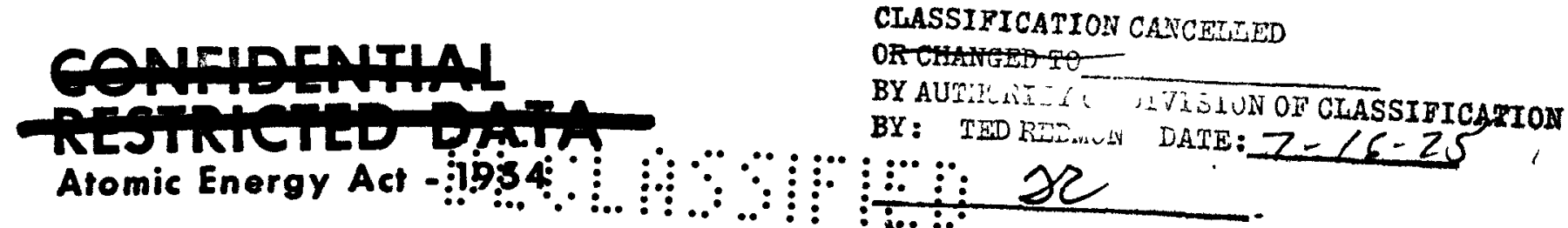


\section{DISCLAIMER}

This report was prepared as an account of work sponsored by an agency of the United States Government. Neither the United States Government nor any agency Thereof, nor any of their employees, makes any warranty, express or implied, or assumes any legal liability or responsibility for the accuracy, completeness, or usefulness of any information, apparatus, product, or process disclosed, or represents that its use would not infringe privately owned rights. Reference herein to any specific commercial product, process, or service by trade name, trademark, manufacturer, or otherwise does not necessarily constitute or imply its endorsement, recommendation, or favoring by the United States Government or any agency thereof. The views and opinions of authors expressed herein do not necessarily state or reflect those of the United States Government or any agency thereof. 


\section{DISCLAIMER}

Portions of this document may be illegible in electronic image products. Images are produced from the best available original document. 
The decision to remove the alignment sleeves on $N R X: A l$ and $N R X-A 2$ was made on the basis that the sleeve as designed was insufficiently strong to withstand the types of loads encountered in KIWI B-4A -- indeed they seemed to be susceptible to failure even in normal handling. Subsequent to failure, or even as a result of minor chipping, they would provide a focal point for catastrophic corrosion due to loss of coating.

The sleeves, had they remained intact, would have limited the maximum mismatch of fuel element and support block coolant holes due to relative rotation of the support block and the fuel element cluster to an approximate value of 14.5 mils. A preliminary estimate of the corresponding value without the sleeves is 26.5 mils, based only on rotation of the support block into contact with its neighbors. Some 94 independent dimensional extremes must occur simultaneously for the 14.5 mil shift to exist, compared with 68 for the 26.5 mil value without sleeves. A statistical survey of the factors contributing to this value is being performed, and the results will be available in the near future.

In calculating the performance effects of such misalignments, it is necessary to combine the expected distribution of such block rotations with the statistical variation of hole location in the fuel elements ( 12 mils maximum) and the support blocks ( 1.5 mils maximum). When such distributions are available, one then combines the probability distribution of given degrees of mismatch with the corresponding hot channel temperature penalty, the resulting temperature distribution is then folded with similar distributions of other off-design conditions leading to higher temperatures.

A preliminary analysis performed for the present situation shows that the maximum coolant channel outlet temperature rise caused by the $28 \mathrm{mil}(14.5+12+1.5)$ misalignment possible without the pins is $308^{\circ} \mathrm{R}$; the corresponding value for the $40 \mathrm{mil}$ case is 7940 R. In considering these numbers, it must be emphasized that:

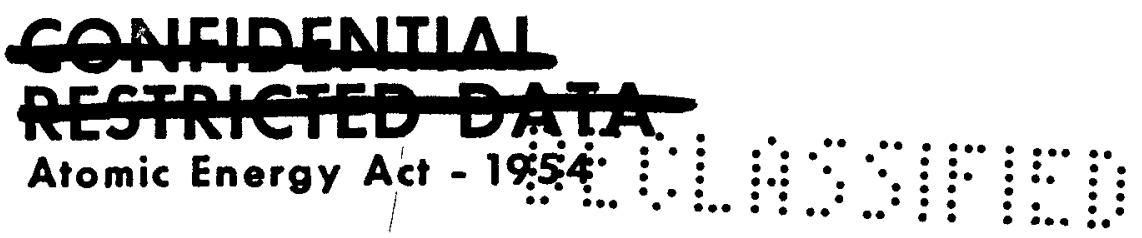




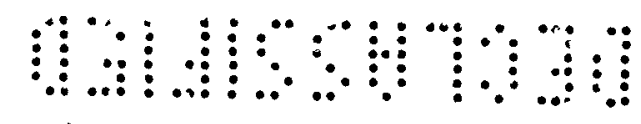

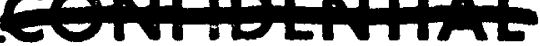

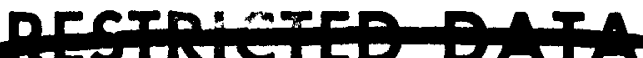

Atomic Energy Act - 1954

Stronuclear

WANL-TME-494

1) The actual misalignment values are distributed in some fashion (based on probability of occurrence) between zero and the maximum value. (Within a given block, the maximum mismatch is reduced for the holes closer to the center of rotation.)

2) The temperature rise values given above for the misalignment cases apply to a high power factor channel (orificed for maximum flow). There is indication from initial stages of the more detailed studies that the channels in the periphery of the core, which are the high power channels, will average smaller misalignment factors.

3) The hot channel temperature rises obtained in this fashion are to be combined in a statistical fashion with many others, at least one of

- which is larger than the effect presently under discussion and which will dominate the resulting distribution. The attached figure, number 561699, shows the results of such an analysis with the misalignment due to rotation entered as a single statistical characteristic. Both the $28 \mathrm{mil}$ and the $40 \mathrm{mil}$ values are assumed to have the same probability of occurrence. Under these assumptions, the elimination of the alignment sleeves has caused a $30-50 \%$ increase in the number of channels which have temperatures higher than a given value.

It must be emphasized that this curve is highly preliminary, not only because the data and assumptions which went into its generation are in the process of being more precisely defined, but also because this calculation assumes that the channel is isolated (no radial conduction), whereas in fact the high temperatures would be considerably relieved by conduction to the cooler channels nearby. A technical memorandum incorporating more defined data and methods is in the process of preparation. This memorandum will also discuss possible alternate designs of more rugged alignment devices which can be incorporated in later reactors. 


\section{$-$}

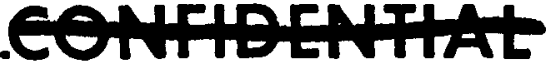

In summary, it is felt that the probable breakage and resulting catastrophic loss by corrosion of at least some of the alignment sleeves dictated that they be removed from the NRX-A2 reactor and, hence, from NRX-A1. The resulting performance penalty is not felt to be a serious problem this early in the program; however, alternate designs with the objective of performance improvements are being considered for incorporation in later reactors.

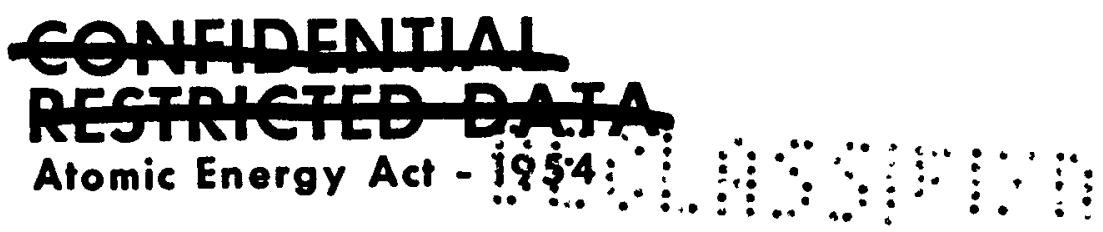

